DOI: https://doi.org/10.24127/ajpm.v10i2.3882

\title{
PROFIL BERPIKIR KRITIS MAHASISWA \\ DALAM MEMECAHKAN MASALAH GEOMETRI \\ DITINJAU DARI ADVERSITY QUOTIENT DAN LEARNING STYLE
}

\author{
Agustina $\mathrm{Mei}^{1}$, Sofia $\mathrm{Sa}^{{ }^{\prime}{ }^{2}}$, Finsensius Yesekiel $\mathrm{Naja}^{3 *}$ \\ 1,2,3* Pendidikan Matematika, Universitas Flores Ende, Indonesia \\ *Corresponding author. \\ E-mail: $\frac{\text { meiagustina612@gmail.com }}{\text { saosofia39@gmail.com }}{ }^{2)}$ \\ naja.finsensius@gamil.com $^{3 *)}$
}

Received 29 June 2021; Received in revised form 12 September 2021; Accepted 27 September 2021

\begin{abstract}
Abstrak
Setiap individu dapat berpikr kritis dalam memecahkan masalah sesuai dengan perbedaan adversity qutient dan learning style yang dimiliki. Penelitian ini bertujuan mendeskripsikan profil berpikir kritis mahasiswa matematika yang memiliki visual, auditory, khinestetik learning style dan adversity quotient climbers dalam memecahkan masalah geometri. Penelitian ini merupakan penelitian deskriptif dengan menggunakan pendekatan kualitatif. Subjek penelitian mahasiswa pendidikan matematika Unversitas Flores. Instrumen dalam penelitian ini adalah peneliti sendiri, angket adversity qutient, angket learning style dan Tes Pemecahan Masalah. Hasil yang diperoleh bahwa 1) Subjek dengan visual learning style dan adversity quotient climbers dalam memecahkan masalah dapat memahami masalah yang dihadapi, dapat meerencanakan dan dapat melaksanakan proses penyelesaian dengan baik, serta memeriksa kembali pekerjaan. 2) Subjek dengan auditory learning style dan adversity quotient climbers dapat memahami masalah yang diberikan, tidak merencanakan sehingga pelaksanaan tidak secara detail, memeriksa kembali pekerjaan. 3) Subjek dengan khinestetik learning style dan adversity quotient climbers dapat memahami masalah, merencanakan namun subjek menyelesaikan secara langsung, tidak memeriksa kembali apa yang telah dikerjakan. Disimpulkan bahwa setiap individu memiliki cara yang berbeda dalam memahami dan memecahkan masalah.
\end{abstract}

Kata kunci: Adversity quotient; berpikir kritis; learning style.

\begin{abstract}
Each individual can think critically in solving problems according to the differences in their adversity quotient and learning style. This study aims to describe the critical thinking profile of mathematics students who have visual, auditory, kinesthetic learning styles and adversity quotient climbers in solving geometry problems. This research is a descriptive study using a qualitative approach. The research subjects were students of mathematics education at the University of Flores. The instruments in this study were the researchers themselves, adversity quotient questionnaires, learning style questionnaires, and Problem Solving Tests. The results obtained are that 1) Subjects with visual learning style and adversity quotient climbers in solving problems can understand the problems at hand, can plan and can carry out the completion process well, and re-examine the work. 2) Subjects with auditory learning style and adversity quotient climbers can understand the problem given, do not plan so that the implementation is not detailed, re-examine the work. 3) Subjects with kinesthetic learning style and adversity quotient climbers can understand the problem, plan but the subject solves it directly, does not re-examine what has been done. It was concluded that each individual has a different way of understanding and solving problems.
\end{abstract}

Keywords: Adversity quotient; critical thinking; learning style.

This is an open access article under the Creative Commons Attribution 4.0 International License 
DOI: https://doi.org/10.24127/ajpm.v10i2.3882

\section{PENDAHULUAN}

Reformasi pendidikan matematika tengah berlangsung di berbagai belhan dunia, termasuk Indonesia, dengan diwarnai diterapkannya pembelajaran yang berorientasi pada kemampuan berpikir tingkat tinggi atau sering disebut high order thinking skill (HOTS) (Sumaryanta, 2018). Salah satu kemampuan berpikir tingkat tinggi adalah berpikir kritis. (Lai, 2011) mengungkapkan dengan berpikir kritis seseorang dapat mengungkap dibalik informasi yang diperoleh sehingga dapat menentukan kecocokan informasi tersebut dengan masalah yang dihadapi. Untuk menilai berpikir kritis seseorang, (Ennis,1985) memperkenalkan enam kriteria berpikir kritis yang disingkat (FRISCO) meliputi: 1) focus yaitu menyebutkan poin utama. 2) reason yaitu memberikan alasan yang mendukung kesimpulan. 3) inference adalah proses penarikan kesimpulan. 4) situation; mengungkap faktor-faktor penting yang perlu dipertimbangkan dalam memutuskan. 5) clarity; menjelaskan istilah-istilah yang digunakan dalam berpendapat. Dan 6) overview yaitu pengecekan kembali. Hal ini sejalan dengan penelitian yang dilakukan oleh Restu dan Haninda yang menemukan bahwa kemampuan seseorang dalam berpikir kritis merupakan kemampuan yang sangat esensial untuk kehidupan, pekerjaan, dan berfungsi efektif dalam semua aspek kehidupan lainnya, (Restu \& Haninda, 2015).

Selain berpikir kritis, disebut juga bahwa salah satu tujuan pembelajaran matematika adalah memiliki kemampuan untuk memecahkan masalah (Depdiknas, 2006). Kemampuan berpikir kritis berkaitan dengan proses peserta didik memecahkan masalah matematika karena berpikir kritis adalah salah satu cara peserta didik untuk mampu mengatasi atau memecahkan masalah (Susandi, 2019). Berpikir kritis merupakan kemampuan berpikir siswa yang sangat penting untuk dikembangkan di sekolah, (Rahimah, 2019). Berpikir kritis berkaitan dengan kemampuan mengidentifikasi, menganalisis, dan memecahkan masalah yang dihadapi dengan tepat berdasarkan analisis dan pengetahuan yang dimilikinya (Ramalisa, 2013). Berpikir kritis dapat diartikan sebagai kemampuan berpikir siswa untuk menarik kesimpulan yang sah, (Kusmanto, 2014). Peserta didik yang dapat berpikir kritis dengan baik dapat memilah informasi yang diperoleh untuk diuji kebenarannya maka peserta didik akan mampu memecahkan masalah (Parameswari \& Kurniyati, 2020). Hal ini sejalan dengan penelitian yang dilakukan oleh David S. Setiana dkk yang menemukan bahwa kemampuan berpikir kritis siswa memiliki tingkatan yang berbeda, (David S. Setiana dkk, 2020).

Berbicara mengenai pemecahan masalah, (Polya, 1978) mengemukakan empat langkah yang harus dilakukan yaitu: 1) memahami masalah (understanding the problem), 2) menyusun rencana penyelesaian (devising a plan), 3) melaksanakan rencana penyelesaian (carrying out the plan), dan 4) memeriksa kembali (looking back). (Shodiqin \& Utomo, 2020) mengungkapkan bahwa masalah yang sering dialami oleh peserta didik adalah sulit untuk memecahkan masalah matematika yang dihadapi dan akan berdampak pada rendahnya hasil belajar, hal ini dikarenakan pengajar dalam proses pembelajaran menggunakan model pembelajaran yang kurang melihat adversity quotient dan learning 
style yang dimiliki oleh setiap individu. Sementara itu (Mulyati, 2016) menyatakan dalam memecahkan masalah matematika setiap individu memiliki cara yang berbeda dalam memecahkannya hal ini dimungkinkan karena perbedaan adversity quotient.

Selain itu juga seseorang dapat menyelesaikan atau memecahkan masalah yang ada dengan baik apabila didukung oleh kemampuan menyelesaikan masalah yang baik pula, (Sumartini, 2018). (Nurhayati \& Fajrianti, 2015) mengungkapkan AQ dapat menjadi indikator untuk melihat seberapa kuatkah seseorang dapat terus bertahan dalam suatu masalah yang sedang dihadapinya. (Afri, 2018) mengungkapkan bahwa Keberhasilan peserta didik dalam memecahkan masalah dipengaruhi oleh adversity quotient (AQ). Hal ini sejalan dengan penelitian yang dilakukan oleh Rany Widyastuti yang menemukan bahwa adversity quotient (AQ) merupakan suatu kemampuan yang dimiliki seseorang dalam menghadapi dan menyelesaikan suatu permasalahan, (Rany Widyastuti, 2015). Terdapat 3 jenis pengelompokan adversity quotient yaitu climber, campers, dan quitters, (Masfingatin, 2013).

Hal lain yang berhubungan dalam proses memecahkan masalah matematika adalah tentang learning style atau gaya belajar. Gaya belajar mengacu kepada cara belajar yang lebih disukai peserta didik (Umrana, Cahyono, \& Sudia, 2019). Pendapat lain juga menyebutkan bahwa masingmasing peserta didik berbeda dalam melakukan pemecahan masalah dan perbedaan tersebut salah satunya dikarenakan gaya belajar masingmasing peserta didik berbeda (Willia, Annurwanda, \& Friantini, 2020). Gaya belajar merupakan salah satu variabel yang penting dimana dengan gaya belajar yang baik mampu membantu anak belajar secara produktif (Imamuddin, Rusdi, Isnaniah, \& Audina, 2019). Hal ini sejalan dengan penelitian yang dilakukan oleh Luk Luk Nur Mufidah yang menemukan bahwa gaya belajar anak adalah salah satu cara untuk meningkatkan potensi dalam diri anak dengan tetap memberikan kesempatan untuk anak belajar sesuai dengan kecenderungan masing-masing, (Mufidah, 2017). Terdapat 3 jenis gaya belajar yaitu visual, auditorial, dan kinestetik (Waskitoningtyas, 2017).

Dalam pelaksanaan pembelajaran di kelas guru harus mengetahui tingkat AQ dan gaya belajar yang dimilki oleh setiap siswa, penelitian ini sangat penting dilakukan agar guru memilih model pembelajaran sesuai dengan tingkat AQ dan gaya belajar yang dimiliki oleh setiap siswa.

Berdasarkan latar belakang tersebut, peneltian ini bertujuan untuk, (1) Mendeskripsikan profil berpikir kritis mahasiswa matematika yang adversity quotient climbers dan learning style visual dalam memecahkan masalah geometri. (2) Mendeskripsikan profil berpikir kritis mahasiswa matematika yang adversity quotient climbers dan learning style auditory dalam memecahkan masalah geometri. (3) Mendeskripsikan profil berpikir kritis mahasiswa matematika yang adversity quotient climbers dan learning style khinestetik dalam memecahkan masalah geometri.

Adapun manfaat yang diharapkan setelah penelitian ini, yaitu: (1) Memberikan informasi tentang kemampuan berpikir kritis mahasiswa matematika agar menjadi bahan pertimbangan kepada dosen matematika dalam merancang dan mengelola proses pembelajaran yang dapat meningkatkan 
kemampuan berpikir kritis mahasiswa dan sesuai dengan adversity quotient climbers dan learning style.

Memberikan bekal kepada mahasiswa matematika sebagai calon guru agar nanti dapat menjadi bahan pertimbangan guru matematika dalam melatih siswa memecahkan masalah.

\section{METODE PENELITIAN}

Penelitian ini merupakan penelitian deskriptif dengan menggunakan pendekatan kualitatif, (Molleong, 2010). Untuk memperoleh data yang dibutuhkan, dilakukan pengambilan data berupa tugas pemecahan masalah (TPM) dan wawancara berkaitan dengan hasil pekerjaan TPM yang telah diberikan. Data yang diperoleh berupa data hasil tes yang akan dianalisis dan disimpul-kan hasilnya, serta data hasil wawancara yang juga akan dianalisis dan disimpulkan.

Subjek penelitian ini adalah mahasiswa pendidikan matematikaFKIP Unversitas Flores yang duduk disemester dua berjumlah 13 orang. Selanjutnya 13 orang mahasiswa akan diberikan angket adversity quotient (AQ), hasil angket akan dianalisis sesuai dengan tipe adversity quotient yakni: 1) quiters, 2) campers, 3) climbers, dalam penelitian ini peneliti hanya mengambil mahasiswa yang memiliki tipe adversity quotient climbers. Selanjutnya mahasiswa yang memiliki tipe adversity quotient climbers akan diberi angket learning style, hasil angket learning style akan dianalisis sesuai dengan learning style masing-masing yakni: 1) visual. 2) auditory, 3) khinestetic. Angket learning style memiliki 30 pernyataan, apabila dari 30 pernyataan yang diberikan mahasiswa menjawab lebih dari 15 jawaban A, maka mahasiswa tersebut memiliki visual learning style.
Apabila dari 30 pernyataan yang diberikan mahasiswa menjawab lebih dari 15 jawaban $\mathrm{B}$, maka mahasiswa tersebut memiliki auditory learning style. Apabila dari 30 pernyataan yang diberikan mahasiswa menjawab lebih dari 15 jawaban $C$, maka mahasiswa tersebut memiliki khinestetik learning style. Untuk menentukan 3 subjek penelitian pada masing-masing kategori akan dipilih dengan kriteria sebagai berikut: 1) untuk 1 subjek visual learning style dipilih dari kelompok visual yang total pilihan jawaban A tertinggi, 2) untuk 1 subjek auditory learning style dipilih dari kelompok auditory yang total jawaban B tertinggi, 3) untuk 1 subjek khinestetik learning style dipilih dari kelompok khinestetic yang total jawaban $C$ tertinggi. Selain kriteria tersebut, mahasiswa juga harus memenuhui kriteria tingkat kemampuan matematika yang sama dan kondisi mahasiswa memiliki sifat terbuka agar mudah diwawancara. Instrumen utama dalam penelitian ini adalah peneliti sendiri. Karena dalam penelitian ini peneliti berperan dalam mengumpulkan, menganalisis dan menginterpretasikan data. Instrumen pendukung dalam penelitian ini adalah angket adversity qutient (AQ), angket learning style dan Tes Pemecahan Masalah (TPM). Teknik pengumpulan data, yaitu: (1) Pemberian TPM dan wawancara.

Teknik pengumpulan data dalam penelitian ini terdiri atas dua bagian yaitu: Pengumpulan data pustaka dan pengumpulan data lapangan yang terdiri dari empat bagian yaitu observasi, pencatatan, wawancara, dokumentasi dan Tes. Untuk menjamin keabsahan data dalam penelitian ini, diperlukan teknik pengujian keabsahan data (Sugiono, 2012). Teknik pengujian keabsahan data menggunakan triangulasi. Triangulasi yang digunakan dalam 
penelitian ini adalah triangulasi waktu. Teknik analisis data wawancara dalam penelitian ini adalah 1) Koleksi data, 2) reduksi data meliputi transkrip data dan seleksi data, 3) Penyajian data, 4) Analisis data, 5) Penarikan kesimpulan.

Prosedur yang dilakukan dalam penelitian ini dimulai dengan pemberian instrumen adversity quotient, kemudian learning style, setelah itu pemberian Tes Pemecahan Masalah (TPM). TPM berupa soal kontekstual pada bidang geometri yag disajikan dalam bentuk cerita. Hasil TPM selanjutnya dianalisis sesuai dengan kriteria berpikir kritis FRISCO pada masing-masing langkah pemecahan masalah Polya yang telah dirumuskan. Berdasarkan data hasil TPM tersebut kemudian dilakukan wawancara terhadap subjek guna mengetahui proses berpikir kritis siswa sesuai dengan adversity qutient dan learning style yang dimiliki oleh setiap subjek.

\section{HASIL DAN PEMBAHASAN}

\section{Hasil Angket Adversity Quotient}

Hasil angket adversity quotient dapat dilihat pada Tabel 1.

Tabel 1. Hasil angket adversity quotient

\begin{tabular}{|c|c|c|c|c|}
\hline \multirow{2}{*}{$\begin{array}{c}\text { Inisial } \\
\text { siswa }\end{array}$} & \multirow{2}{*}{$\mathbf{L} / \mathbf{P}$} & \multicolumn{3}{|c|}{ Bagian } \\
\hline & & $\mathbf{Q}$ & $\mathrm{Cm}$ & $\mathrm{Cl}$ \\
\hline VA & $\mathrm{L}$ & $\mathrm{V}$ & & \\
\hline MFG & $\mathrm{P}$ & & & $\mathrm{V}$ \\
\hline MKT & $\mathrm{P}$ & & & $\mathrm{v}$ \\
\hline FLO & $\mathrm{P}$ & & & $\mathrm{v}$ \\
\hline $\mathrm{TE}$ & $\mathrm{P}$ & & & $\mathrm{v}$ \\
\hline PSW & $\mathrm{P}$ & & & $\mathrm{v}$ \\
\hline MPM & $\mathrm{P}$ & & & $\mathrm{v}$ \\
\hline FS & $\mathrm{P}$ & & & $\mathrm{v}$ \\
\hline EW & $\mathrm{P}$ & & & $\mathrm{v}$ \\
\hline ESP & $\mathrm{P}$ & & & $\mathrm{V}$ \\
\hline MTN & $\mathrm{P}$ & & & $\mathrm{V}$ \\
\hline SFN & $\mathrm{P}$ & & & $\mathrm{v}$ \\
\hline PMJ & $\mathrm{P}$ & & & $\mathrm{V}$ \\
\hline
\end{tabular}

Q: Quiters, Cm: Campers, Cl: Climbers
Dari hasil angket adversity quotient pada Tabel 1. terdapat 1 mahasiswa memiliki tipe adversity quotient quiters dan 12 mahasiswa memiliki tipe adversity quotient climbers. Kemudian 12 orang mahasiswa yang memiliki tipe adversity quotient climbers diberikan lagi angket Learning Style, hasil angket disajikan pada Tabel 2.

\section{Hasil Angket Learning Style}

Hasil angket Learning Style dapat dilihat pada Tabel 2 .

Tabel 2. Hasil Angket Learning Style

\begin{tabular}{ccccc}
\hline Inisial & $\mathrm{L} / \mathrm{P}$ & \multicolumn{3}{c}{ Jawaban } \\
\cline { 3 - 5 } siswa & & $\mathrm{A}$ & $\mathrm{B}$ & $\mathrm{C}$ \\
\hline VA & $\mathrm{L}$ & 9 & 16 & 5 \\
MFG & $\mathrm{P}$ & 7 & 15 & 8 \\
MKT & $\mathrm{P}$ & 16 & 11 & 3 \\
FLO & $\mathrm{P}$ & 15 & 11 & 4 \\
TE & $\mathrm{P}$ & 7 & 8 & 15 \\
PSW & $\mathrm{P}$ & 7 & 7 & 16 \\
MPM & $\mathrm{P}$ & 17 & 6 & 7 \\
FS & $\mathrm{P}$ & 8 & 7 & 15 \\
EW & $\mathrm{P}$ & 16 & 9 & 5 \\
ESP & $\mathrm{P}$ & 6 & 15 & 9 \\
MTN & $\mathrm{P}$ & 7 & 16 & 7 \\
SFN & $\mathrm{P}$ & 16 & 6 & 8 \\
PMJ & $\mathrm{P}$ & 6 & 8 & 16 \\
\hline
\end{tabular}

Ket. A: Visual, B: Auditori, C: Khinestetik

Dari hasil angket Learning Style pada Tabel 2, terdapat 5 mahasiswa memiliki visual learning style, 4 mahasisiwa memiliki auditory learning style dan 4 mahasiswa memiliki khinestetic learning style. Dari ketiga kelompok learning style dan tipe adversity quotient climbers maka dipilih masing-masing satu subjek yang memenuhi kriteria yakni subjek visual learning style memiliki tipe adversity quotient climbers berinisial (MPM). Subjek auditory learning style memiliki tipe adversity quotient climbers berinisial (MTN). Subjek khinestetic 
learning style memiliki tipe adversity quotient climbers berinisial (PSW), ketiga subjek tersebut akan diberikan Tes Pemecahan Masalah.

\section{Profil Berpikir Kritis Subjek visual learning style memiliki tipe Adversity Quotient Climbers dalam Memecahkan Masalah}

Hasil Tes pemecahan masalah subjek MPM disajkan pada Gambar 1.

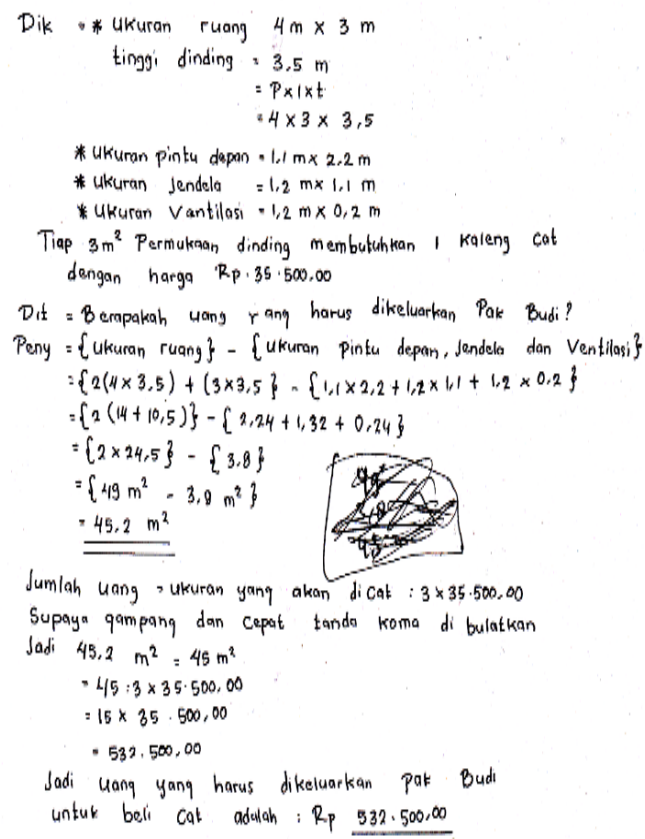

Gambar 1. Hasil tes pemecahan masalah subjek MPM

Berikut ini cuplikan wawancara subjek dalam memahami masalah.

$\mathrm{P}$ : Tolong adik baca kembali soalnya

VC : (Subjek membaca soal). Sudah bu

P : Menurut adik, apa yang menjadi masalah dalam soal tersebut?

VC : (Subjek kembali melihat lembar soal sesaat kemudian menjawab) yang menjadi masalah adalah agak susah Bu
P : Maksud ibu begini, inikan ada soal cerita terus yang menjadi masalah itu apanya?

VC : (Sejenak terdiam sambil mencoret-coret lembar soal kemudian menjawab) masalahnya adalah ukurannya dan luas daerah $\mathrm{Bu}$

Selanjutnya, disajikan cuplikan wawancara subjek dalam merencanakan penyelesaian.

P : Tolong adik baca kembali soalnya. Setelah adik memahami masalah ini berarti adik sudah berpikir bagaimana cara menyelesaikan masalah ini kan?

$\mathrm{VC}$ : Iya bu

$\mathrm{P} \quad$ : Terus cara apa yang adik rencanakan untuk menjawab masalah ini?

VC : (Terdiam sejenak, kemudian menjawab) saya menggunakan cara langsung bu

P : Maksud cara langsung itu bagaimana?

VC : Maksudnya caranya itu harus mengetahui ukuran ruang kepala sekolah tanpa lantai dan atap, langsung dikurangi dengan ukuran pintu, ukuran jendela dan ukuran ventilasi

$\mathrm{P}$ : Mengapa adik memilih cara ini?

VC : Lebih gampang dan lebih cepat bu

Berlanjut dengan cuplikan wawancara subjek dalam melaksanakan penyelesaian.

$\mathrm{P} \quad$ : Nah sekarang tolong adik jelaskan langkah-langkah penerapannya dari cara yang telah adik pilih tadi

VC : (Terdiam sambil melihat hasil pekerjaan) begini bu 
DOI: https://doi.org/10.24127/ajpm.v10i2.3882

(menunjuk lembar pekerjaan

P : Oh,,, begini maksudnya? (menunjuk perhitungan luas seluruh dinding)

VC : Iya bu

$\mathrm{P}$ : Ini mengapa harus dibagi 3? (menunjuk : 3 pada lembar pekerjaan)

VC : (Sambil melihat hasil pekerjaannya, kemudian menjawab) karena inikan bu, yang diketahuikan tiap kaleng dapat mengecat permukaan seluas $3 \mathrm{~m}^{2}$

$\mathrm{P}$ : Terus?

VC : Terus, mebutuhkan 1 kaleng cat

$\mathrm{P} \quad$ : Selanjutnya?

VC : Iya bu, Nanti dibagi 3, baru dikali dengan harga cat, yaitu $35.500,00$ dan supaya gampang, 45,2 $\mathrm{m}^{2}$ ini harus dibulatkan jadi $45 \mathrm{~m}^{2}$ saja

$\mathrm{P}$ : Bagaimana rumus luas persegi panjang?

VC : Rumusnya panjang $\times$ lebar

Dilanjutkan dengan cuplikan wawancara subjek dalam memeriksa kembali.

$\mathrm{P} \quad$ : Setelah adik mengerjakan semua ini, dari awal sampai mengetahui uang yang harus dikeluarkan untuk membeli cat tersebut, sebelum dikumpul-kan apa adik memeriksanya lagi dari awal?

VC : Iya bu, saya sudah memeriksa semuanya

P : Yang mana saja yang adik periksa?

VC : Dari cerita soalnya, terus,,,yang diketahui, yang ditanyakan, alasannya dan hasilnya

$\mathrm{P} \quad$ : Kenapa harus diperiksa lagi?

VC : (Tersenyum, kemudian menjawab) mungkin saja ada kekeliruan, supaya bisa diperbaiki
Berdasarkan hasil wawancara dan lembar jawaban yang diberikan oleh subjek visual learning style dan adversity quotient climbers dapat diketahui bahwa subjek ketika memahami masalah, menyatakan bahwa masalah pada TPM adalah luas daerah. Selanjutnya, subjek menjelaskan inferensinya bahwa terlebih dahulu harus mengetahui luas seluruh ruang dan luas daerah yang tidak dicat.

Subjek mengetahui semua informasi yang disajikan dalam soal dan memahami apa yang ditanyakan dalam soal. Subjek juga dapat menjelaskan maksud ukuran dinding yaitu, luas daerah. Subjek memeriksa kembali pemahamannya terhadap masalah yang dihadapi dengan menuliskan satu persatu dan membaca ulang kembali.

Subjek ketika merencanakan mengerjakan masalah TPM memilih cara langsung karena menurut dia cara langsung lebih cepat dan mudah, yaitu langsung menghitung luas daerah, selanjutnya mencari biaya yang harus dikeluarkan. Subjek juga mengetahui hal-hal yang akan dilakukan ketika menerapkan rencananya. Subjek memeriksa kembali hal-hal yang telah dilakukan dengan menuliskan satu persatu dan membaca kembali.

Subjek ketika melaksanakan rencana, terlebih dahulu menghitung luas daerah yang akan dicat. Langkah tersebut dia lakukan karena berdasarkan apa yang sudah direncanakan sebelumnya. Subjek juga mengetahui langkah-langkah penyelesaiannya, awalnya subjek menghitung luas daerah yang akan dicat, selanjutnya membagi dengan luas daerah yang dapat dicat perkaleng cat, sehingga subjek dapat menghitung besarnya uang yang harus dikeluarkan. Subjek memeriksa kembali semua hal-hal yang telah dilakukan saat melaksanakan rencana. 
DOI: https://doi.org/10.24127/ajpm.v10i2.3882

Selanjutnya subjek memeriksa kembali hasil pekerjaannya agar bisa memperbaiki jika ada kekeliruan atau kesalahan pada jawabannya. Subjek mengetahui hal-hal penting yang harus diperiksa, yaitu memeriksa soal, jawaban dan alasan. Selanjutnya subjek mampu menjelaskan maksudnya memeriksa dengan memperhatikan angka-angkanya yaitu pada proses perhitungan. Subjek tidak memeriksa kembali hal-hal yang telah dilakukan dalam memeriksa jawabannya.

Penelitian ini telah melengkapi dan memperkuat penelitian sebelumnya mengenai analisis berpikir kritis siswa ditinjau dari gaya belajar yang dilakukan oleh David S. Setiana dkk (2020), dari penelitian yang dilakukan menunjukan hasil penelitian bahwa kemampuan berpikir kritis siswa pada masing-masing gaya belajar memiliki tingkatan yang berbeda, siswa dengan gaya belajar visual memiliki kemampuan berpikir kritis sangat baik.

Yang membedakan dengan penelitian sebelumnya penelitian ini ingin mengetahui profil berpikir kritis mahasiswa dengan gaya belajar visual yang memiliki tingkat adversity quotient (AQ), karena tingkat $\mathrm{AQ}$ sangat diperlukan dalam memecahkan masalah, hal ini sejalan dengan penelitian yang dilakukan Rany Widyastuti (2015) yang menyatakan bahwa AQ merupakan suatu kemampuan yang dimiliki seseorang dalam menghadapi dan menyelesaikan suatu permasalahan.

\section{Profil Berpikir Kritis Subjek auditory learning style memiliki tipe Adversity Quotient Climbers dalam Memecahkan Masalah}

Hasil Tes pemecahan masalah subjek MTN disajkan pada Gambar 2.

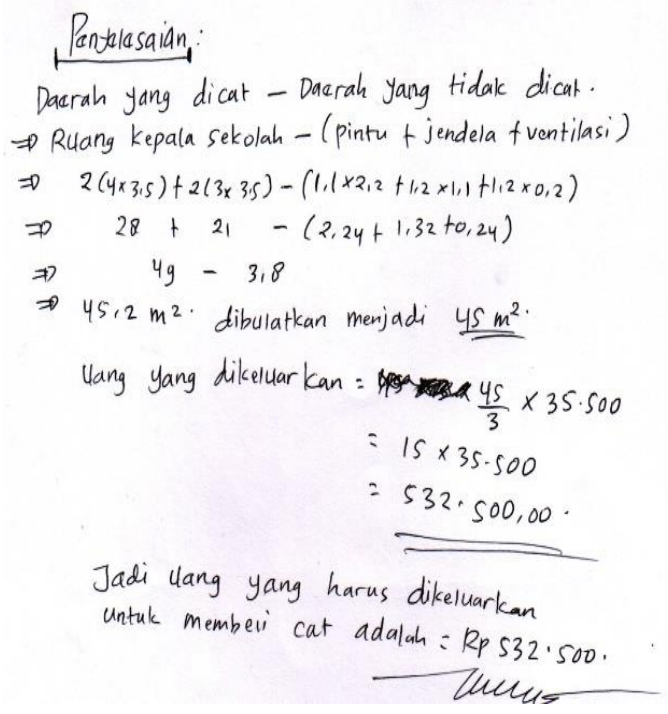

Gambar 2. Hasil tes pemecahan masalah subjek MTN

Berikut ini cuplikan wawancara subjek dalam memahami masalah.

$\mathrm{P}$ : Tolong adik baca kembali soalnya.

AC : (Subjek membaca soal dengan bersuara). Sudah bu

$\mathrm{P}$ : Menurut adik, apa yang menjadi masalah dalam TPM I tersebut?

AC : (Sesaat terdiam, kemudian menjawab) yang menjadi masalah adalah uang yang harus dikeluarkan untuk membeli cat

$\mathrm{P}$ : Kenapa adik menyimpulkan seperti itu? Apa alasannya?

AC : (Terdiam sejenak, kemudian menjawab) Ini bu, (membaca soal) berapakah biaya yang harus dikeluarkan pak Budi untuk membeli cat.

Dilanjutkan dengan cuplikan wawancara subjek dalam merencanakan penyelesaian.

$P$ : Setelah adik memahami masalah ini berarti adik sudah berpikir bagaimana cara menyelesaikan masalah ini kan?

AC : Iya Bu, sudah 
DOI: https://doi.org/10.24127/ajpm.v10i2.3882

P : Terus cara apa yang adik rencanakan untuk menjawab masalah ini?

AC : (Terdiam sejenak, kemudian menjawab) caranya mencari ukuran ruang lalu dikurangi dengan ukuran pintu, ukuran jendela dan ukuran ventilasi.

Dilanjutkan dengan cuplikan wawancara subjek dalam melaksanakan penyelesaian.

$\mathrm{P}$ : Nah sekarang tolong adik jelaskan langkah-langkah penerapannya dari cara yang telah adik pilih tadi.

AC : (Terdiam sejenak, kemudian menjawab) Begini bu pekerjaan saya, (menunjuk lembar pekerjaan)

P : Oh,,, jadi begini cara kerjanya? (menunjuk perhitungan luas seluruh dinding)

AC : (Mengangguk)

$\mathrm{P}$ : Terus kenapa ini harus dibagi 3? (menunjuk : 3 pada lembar jawaban)

AC : (Sambil melihat hasil pekerjaannya, kemudian menjawab) karena yang diketahui pada soal bahwa inikan tiap kaleng dapat mengecat permukaan seluas $3 \mathrm{~m}^{2}$

$\mathrm{P} \quad$ : Lalu?

AC : Lalu dibagi 3, baru dikali dengan $35.500,00$

Kemudian, dilanjutkan dengan cuplikan wawancara subjek dalam memeriksa kembali.

$\mathrm{P}$ : Setelah adik mengerjakan semua, dari awal sampai mengetahui biaya yang harus dikeluarkan untuk membeli cat, apakah adik memeriksanya lagi?

$\mathrm{AC}$ : Iya bu, saya sudah memeriksa semuanya

$\mathrm{P} \quad$ : Yang mana saja yang diperiksa?
AC : Dari awal bu, dari yang diketahui, yang ditanyakan dan hasilnya

$\mathrm{P} \quad$ : Kenapa harus diperiksa lagi?

AC : (Terdiam sejenak, kemudian menjawab) Agar tidak ada yang salah

Berdasarkan hasil wawancara dan lembar jawaban yang diberikan oleh subjek auditory learning style dan adversity quotient climbers dapat diketahui bahwa subjek ketika memahami masalah menyatakan bahwa masalah pada TPM adalah biaya yang dikeluarkan untuk membeli cat.

Selanjutnya subjek menjelaskan inferensinya bahwa terlebih dahulu harus menghitung ukuran ruang dan ukuran daerah yang tidak dicat. subjek mengetahui semua informasi yang disajikan dalam soal dan mengetahui apa yang ditanyakan dalam soal. Subjek dapat menjelaskan maksud ukuran ruang yaitu luas daerah. Subjek tidak memeriksa kembali pemahamannya.

Subjek merencanakan mengerjakan masalah TPM yaitu langsung menghitung ukuran ruang, ukuran pintu, ukuran jendela dan ukuran ventilasi selanjutnya mencari biaya yang harus dikeluarkan. Subjek menjelaskan inferensinya bahwa dengan menggunakan cara tersebut lebih simpel dan cepat tapi tetap detail. Subjek mengetahui hal-hal yang akan dilakukan ketika menerapkan rencananya. Subjek memeriksa kembali hal-hal yang telah dilakukan ketika membuat rencana.

Subjek dalam melaksanakan rencana terlebih dahulu menghitung ukuran ruang, langkah tersebut dilakukan karena berdasarkan apa yang sudah direncanakan sebelumnya. Subjek juga mengetahui langkah-langkah penyelesaiannya, awalnya subjek menghitung luas daerah, selanjutnya 
membagi dengan luas daerah yang dapat dicat perkaleng cat, sehingga subjek dapat menghitung besarnya biaya yang harus dikeluarkan. Subjek memeriksa kembali semua hal-hal yang telah dilakukan dengan cara melihat dan membaca lagi.

Selanjutnya subjek memeriksa kembali hasil pekerjaannya agar bisa memperbaiki jika ada kekeliruan atau kesalahan pada jawabannya. Subjek mengetahui hal-hal penting yang diperiksa, yaitu memeriksa apa yang diketahui, yang ditanyakan dan hasilnya. Selanjutnya subjek mampu menjelaskan maksudnya memeriksa dengan memperhatikan angka-angka dan proses perhitungan. Subjek memeriksa kembali hal-hal yang telah dilakukan dalam memeriksa jawabannya.

Penelitian ini telah melengkapi dan memperkuat penelitian sebelumnya mengenai analisis berpikir kritis siswa ditinjau dari gaya belajar yang dilakukan oleh David S. Setiana dkk (2020), dari penelitian yang dilakukan menunjukan hasil penelitian bahwa kemampuan berpikir kritis siswa pada masing-masing gaya belajar memiliki tingkatan yang berbeda, siswa dengan gaya belajar auditori memiliki kemampuan berpikir kritis pada kriteria cukup. Yang membedakan dengan penelitian sebelumnya penelitian ini ingin mengetahui profil berpikir kritis mahasiswa dengan gaya belajar visual yang memiliki tingkat adversity quotient (AQ), karena tingkat AQ sangat diperlukan dalam memecahkan masalah, hal ini sejalan dengan penelitian yang dilakukan Rany Widyastuti (2015) yang menyatakan bahwa AQ merupakan suatu kemampuan yang dimiliki seseorang dalam menghadapi dan menyelesaikan suatu permasalahan.

\section{Profil Berpikir Kritis Subjek khinestetik learning style memiliki tipe Adversity Quotient Climbers dalam Memecahkan Masalah}

Hasil Tes pemecahan masalah subjek MTN disajkan pada Gambar 3.

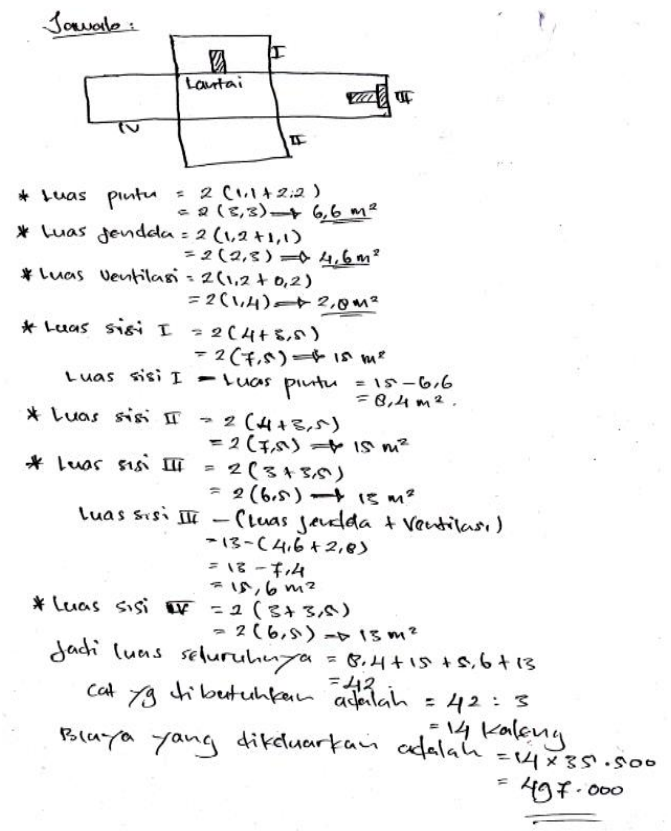

Gambar 3. Hasil tes pemecahan masalah subjek PSW

Berikut cuplikan wawancara subjek dalam memahami masalah.

$\mathrm{P} \quad$ : Tolong adik baca kembali soal

KC : (Subjek membaca soal dengan sedikit bersuara) Sudah bu

$\mathrm{P} \quad$ : Ok, menurut adik, apa yang menjadi masalah dalam TPM I tersebut?

$\mathrm{KC}$ : (Subjek mengangkat lembar soal dan kembali membaca, kemudian menjawab) yang menjadi masalah adalah uang yang harus dikeluarkan pak Budi untuk membeli cat

Berikut cuplikan wawancara subjek dalam merencanakan penyelesaian:

$\mathrm{P} \quad$ : Kemudian cara apa yang adik putuskan akan dipakai? 
DOI: https://doi.org/10.24127/ajpm.v10i2.3882

KC : (Terdiam sejenak, sambil memainkan balpoinnya, kemudian menjawab) Saya hitung luas pintu, luas jendela dan luas ventilasi kemudian menghitung sisinya satu-satu.

$\mathrm{P} \quad$ : Sisi apa?

KC : Sisi tembok bu. kemudian dikurangkan dengan sisi yang ada pintu, sisi yang ada jendela dan ventilasi

P : Jadi adik gambarkan ruang dengan satu pintu, satu jendela dan satu ventilasi pada masingmasing sisi tembok? (coba tunjukan gambarmu)

KC : Ini bu, (menunjuk gambar pada lembar jawaban)

Dilanjutkan dengan cuplikan wawancara subjek dalam melaksanakan penyelesaian

P : Apa saja yang adik lakukan ketika adik mengerjakan ini tadi? Menghitung apa saja?

KC : (Terdiam sejenak, kemudian menjawab) menghitung luas pintu, luas jendela dan luas ventilasi. Setelah itu menghitung sisinya.

$\mathrm{P} \quad$ : Terus diapakan?

KC : Dikurangkan bu

$\mathrm{P}$ : Maksudnya?

KC : (Terdiam sejenak, melihat lembar jawaban, kemudian menjawab) menunjukan sketsa gambar, lalu menjawab dikurangi dengan benda-benda yang tidak dicat, lalu dibagi 3 , karena tiap $3 \mathrm{~m}^{2}$ membutuhkan 1 kaleng cat, jadi luas sisi seluruh yang akan dicat dibagi dengan 3. Setelah itu dapat 14 kaleng

$\mathrm{P} \quad$ : Kemudian?

KC : Dikali dengan harga cat

$\mathrm{P}$ : Oh,,, jadi hasilnya?

KC : 497.000
Diakhiri dengan cuplikan wawancara subjek dalam memeriksa kembali.

$\mathrm{P}$ : Setelah adik mengerjakan semua pekerjaan adik ini tadi, apakah adik memeriksa kembali pekerjaan adik?

KC : Tidak bu, saya tidak memeriksa kembali

$\mathrm{P} \quad$ : Mengaa adik tidak mengecek lagi pekerjaan?

$\mathrm{KC}$ : Iya bu, pikiran saya sudah benar, dan juga waktunya hampir mau selesai

Berdasarkan wawancara dan lembar jawaban yang diberikan oleh subjek khinestetik learning style dan adversity quotient climbers dapat diketahui bahwa subjek dalam memahami masalah, menyatakan bahwa masalah dalam TPM adalah jumlah uang yang dikeluarkan untuk membeli cat. Subjek merumuskan masalah tersebut karena pada kalimat yang terdapat pada soal. Ketika diminta untuk menjelaskan proses inferensinya, subjek menyatakan luas ruang dibagi dengan luas daerah yang dapat dicat perkaleng cat. Subjek mengetahui seluruh informasi yang ada dalam soal. Subjek juga menjelaskan maksud dari ukuran ruang yang ia sebutkan adalah ukuran lantainya. Selanjutnya subjek tidak memeriksa kembali hal-hal yang dilakukan pada saat memahami masalah.

Subjek merencanakan penyelesaian dengan menggambarkan sketsa ruang kepala sekolah. Subjek merencanakan untuk menghitung luas pintu, luas jendela dan luas ventilasi, kemudian menghitung satu-satu sisi dinding sesuai dengan yang telah digambarkan. Selanjutnya subjek menjelaskan proses inferensinya menurut subjek akan lebih cepat mengerjakannya terlebih dahulu 
menghitung luas pintu, jendela dan ventilasi, subjek mengakui bahwa ia baru mengetahui setiap hal yang ia harus hitung ketika ia membaca soal dan langsung menghitugnya.

Subjek menjelaskan tentang persegipanjang adalah memiliki pamjang dan lebar, Sedangkan luas persegipanjang adalah daerah yang dibatasi oleh panjang dan lebar. Subjek menyatakan bahwa ia tidak memeriksa kembali apa yang telah direncanakan. Subjek menjelaskan langkah-langkah penyelesaiannya yaitu setelah diperoleh luas dinding, selanjutnya dibagi dengan luas daerah yang dapat dicat perkaleng cat. Selanjutnya ketika ditanya tentang rumus luas persegipanjang subjek mengatakan panjang kali lebar. Subjek mengatakan setelah mengerjakan ia memeriksa kembali dengan memperhatikan angka-angka dan hasil akhirnya subjek menyatakan bahwa ia tidak memeriksa kembali hasil pekerjaannya.

Penelitian ini telah melengkapi dan memperkuat penelitian sebelumnya mengenai analisis berpikir kritis siswa ditinjau dari gaya belajar yang dilakukan oleh David S. Setiana dkk (2020), dari penelitian yang dilakukan menunjukan hasil penelitian bahwa kemampuan berpikir kritis siswa pada masing-masing gaya belajar memiliki tingkatan yang berbeda, siswa dengan gaya belajar khinestetik memiliki kemampuan berpikir kritis pada kriteria cukup. Yang membedakan dengan penelitian sebelumnya penelitian ini ingin mengetahui profil berpikir kritis mahasiswa dengan gaya belajar visual yang memiliki tingkat adversity quotient (AQ), karena tingkat $\mathrm{AQ}$ sangat diperlukan dalam memecahkan masalah, hal ini sejalan dengan penelitian yang dilakukan Rany Widyastuti (2015) yang menyatakan bahwa AQ merupakan suatu kemampuan yang dimiliki seseorang dalam menghadapi dan menyelesaikan suatu permasalahan.

\section{KESIMPULAN DAN SARAN}

Berdasarkan hasil analisis dan pembahasan yang telah dijelaskan maka dapat disimpulkan bahwa berpikir kritis setiap mahasiswa memiliki cara yang berbeda-beda dalam memecahkan masalah geometri, hal ini dikarenakan perbedaan adversity qutient (AQ) dan learning style atau gaya belajar yang dimiliki setiap individu.

Saran untuk penelitian selanjutnya bahwa penelitian ini menjadi bahan referensi untuk mengkaji model pembelajaran yang sesuai dengan adversity quotient (AQ) dan learning style atau gaya belajar yang dimiliki oleh setiap individu.

\section{DAFTAR PUSTAKA}

Afri, L. D. (2018). Hubungan Adversity Quotient dengan Kemampuan Pemecahan Masalah Siswa SMP pada Pembelajaran Matematika. Axiom, VII(2), 47-53.

Depdiknas. (2006). Kurikulum Tingkat Satuan Pendidikan. Jakarta, PT Gramedia Pustaka Utama.

Ennis, R. H., \& Weir, E. (1985). The Ennis-Weir Critical Thinking Essay Test.

Imamuddin, M., Rusdi, Isnaniah, \& Audina, M. (2019). Kemampuan Pemecahan Masalah Matematika Siswa Berdasarkan Gaya Belajar. AL Khawarizmi, 3(1), 11-20.

Kusmanto, H. (2014). Pengaruh Berpikir Kristis Terhadap Kemampuan Siswa dalam Memecahkan Masalah Matematika (Studi Kasus di Kelas VII SMP Wahid Hasyim Moga). EduMA, 3(1), 92-106.

Lai, E. (2011). Critical Thinking, A Literature Review. Research Report:1-49. 
DOI: https://doi.org/10.24127/ajpm.v10i2.3882

Masfingatin, T. (2013). PROSES BERPIKIR SISWA SEKOLAH MENENGAH PERTAMA DALAM MEMECAHKAN MASALAH MATEMATIKA DITINJAU DARI ADVERSITY QUOTIENT ( Penelitian dilakukan di MTs Negeri Dolopo Tahun Ajaran 2011 / 2012 ). JIPM: Jurnal Ilmiah Pendidikan Matematika, 2(1), 1-8.

Molleong, L. J. (2010). Metodologi Penelitian Kualitatif. Yogyakarta: Bandung. PT Remaja Rosdakarya. Edisi Revisi.

Mulyati, T. (2016). Kemampuan Pemecahan Masalah Matematis Siswa Sekolah Dasar. EduHumaniora | Jurnal Pendidikan Dasar Kampus Cibiru, 3(2), 143148.

https://doi.org/10.17509/eh.v3i2.28 07

Nurhayati, N., \& Fajrianti, N. (2015). Pengaruh Adversity Quotient (AQ) dan Motivasi Berprestasi terhadap Prestasi Belajar Matematika. Formatif: Jurnal Ilmiah Pendidikan MIPA, 3(1), 72-77. https://doi.org/10.30998/formatif.v3 i1.110

Parameswari, P., \& Kurniyati, T. (2020). Kemampuan Berpikir Kritis Siswa dalam Memecahkan Masalah Matematika. JPM Jurnal Pendidikan Matematika, 6(2), 8997.

Polya, G. (1978). How to solve it: a new aspect of mathematical method second edition. The Mathematical Gazette, Vol. 30, p. 181.

Rahimah, N. (2019). Profil Berpikir Kritis Siswa dalam Memecahkan Masalah Matematika Berdasarkan Kemampuan Matematika. LENTERA Jurnal Ilmiah Kependidikan, 14(1), 59-68.

Ramalisa, Y. (2013). Proses BErpikir Kritis SIswa SMA Tipe Kepribadian Thinking dalam
Memecahkan Masalah Matematika. Edumatica, 03(01), 42-47.

Shodiqin, A., \& Utomo, P. W. (2020). Profil Pemecahan Masalah Menurut Krulik Dan Rudnick Ditinjau Dari Kemampuanan Wolfram Mathematica. (201920).

Sugiono. (2012). Metode Penelitian Kualitatif Sugiyono. Mode Penelitian Kualitatif, 5(January), 15.

Sumartini, T. S. (2018). Peningkatan Kemampuan Pemecahan Masalah Matematis Siswa melalui Pembelajaran Berbasis Masalah. Mosharafa: Jurnal Pendidikan Matematika, 5(2), 148-158. https://doi.org/10.31980/mosharafa. v5i2.270

Sumaryanta. (2018). PENILAIAN HOTs DALAM PEMBELAJARAN MATEMATIKA. Indonesian Journal of Mathematics and Education, 8(8), 500-509.

Susandi, A. D. (2019). Identifikasi Kemampuan Berpikir Kritis dalam Memecahkan Masalah Matematika. SIGMA, 6(1), 26-41.

Umrana, Cahyono, E., \& Sudia, M. (2019). Analisis Kemampuan Pemecahan Masalah Matematis Ditinjau dari Gaya Belajar Siswa. Jurnal Pembelajaran Berpikir Matematika, 4(1), 67-76.

Waskitoningtyas, R. S. (2017). PROBLEM SOLVING ABILITIES ARE REVIEWED IN THE LEARNING STYLE OF UNIVERSITY STUDENTS IN MATHEMATICS AT BALIKPAPAN UNIVERSITY. AKSIOMA: Jurnal Program Studi Pendidikan Matematika, 6(3), 432440.

Willia, A., Annurwanda, P., \& Friantini, R. N. (2020). Proses Pemecahan Masalah Matematika Ditinjau Dari Gaya Belajar Siswa. AlphaMath Journal of Mathematics Education, 6(2), 116-128. 